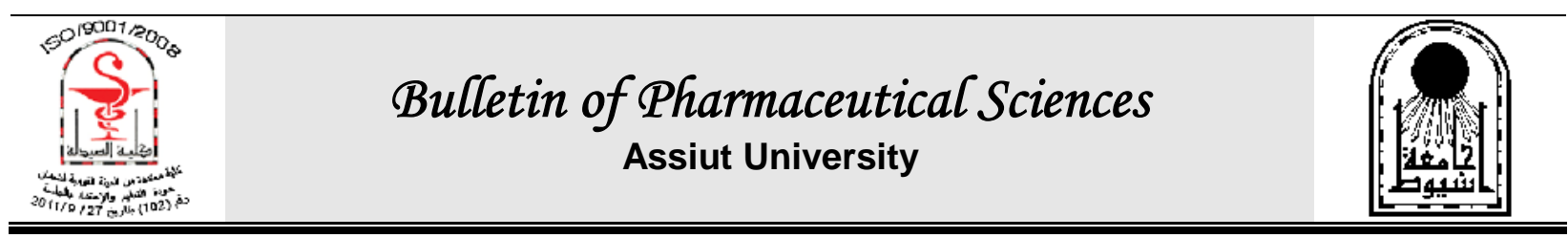

\title{
NOSOCOMIAL ACINETOBACTER INFECTION IN ASSIUT UNIVERSITY HOSPITAL
}

\author{
Isamil Seddek Soliman, Ahmed Sadek Ahmed, Enas Abd-El-Meged Deaf and \\ Ibrahim Mohamoud Sayed
}

\section{Department of Microbiology and Immunology, Faculty of Medicine, Assuit University, Egypt}

\begin{abstract}
Aim:This study aimed to isolation of Acinetobacter spp, detect resistance patterns of isolated strains, phenotypic and genotypic detection of Metallo- $\beta$-lactamase and typing of isolated strains from clinical and environmental respectively.

Material and method: this study includes 440 different clinical specimens, 672 environmental samples, inoculated on different culture media, confirmation of isolates by API20NE, PCR to detect 16SrRNA-23SrRNA gene, determine susceptibility pattern of isolates to different antibiotics and phenotypic and Genotypic detection of bla-OXA 51-like gene.

Result: 24 strains of Acinetobacter (5.45\%) were isolated from 440 clinical samples, 27 strains of Acinetobacter were isolated from 672 environmental samples (4.017\%). Tetracycline was the most active drug against multi-drug resistant A.baumannii. (48/51 or 94\%) of Acinetobacter isolates showed increase in zone of inhibition around IPM/EDTA disc compared with IPM disc alone. (49/51 or 96\%) of Acinetobacter isolates were detected by presence of 16srRNA 23srRNA gene (universal gene present in all Acinetobacter species). (49/51 or 96\%) of isolated Acinetobacter spp showed band with blaOXA-51-like"genes. (37/51 or 72.5\%) Acinetobacter isolates showed positive bands for class I integrase gene (gene responsible for multi drug resistance and outbreaks in hospitals).
\end{abstract}

\section{INTRODUCTION}

Nosocomial Infection means any infection appears on patient after 48 hour from hospital admission, this infection is mainly acquired from hospital and has serious effects on risk factor patients. Infections with A. baumannii tend to occur in debilitated patients, mostly in ICUs. Residents of long-term care facilities, particularly facilities caring for ventilatordependent patients, are at increased risk. In addition to a stay in the ICU, risk factors for colonization and infection are recent surgery, central vascular catheterization, tracheostomy, mechanical ventilation, enteral feedings, and treatment with third-generation cephalosporin, fluoroquinolone, or carbapenem antibiotics ${ }^{1}$.

Acinetobacter is a saprophytic bacterium found in living organisms and inanimate beings. Owing to its scarce virulence, the great majority of infections are produced in the hospital environment, with a greater incidence in patients who are seriously ill and even in a critical state, with central venous lines, vesicle probes, mechanical ventilation, etc. Acinetobacter can also be found in the soil, water, pasteurized milk, frozen food, hospital air-conditioning systems, water deposits, dialysis fluids, hospital mattresses, humidifiers, and oxygen systems ${ }^{2}$.

The emergence and rapid spread of multidrug-resistant isolates causing nosocomial infections are of great concern worldwide. During the last decade, nosocomial infections caused by multidrug-resistant A. baumannii have been reported ${ }^{3}$. Since then, strains of $A$. baumannii have also gained resistance to newly developed antimicrobial drugs. Although multidrug resistant (MDR) A. baumannii is rarely found in community isolates, it became prevalent in many hospitals ${ }^{4}$. 
There is mounting evidence that A.baumannii has a naturally occurring carbapenemase gene intrinsic to this species. The first report of this gene described blaOXA$51^{6}$ but since then a large number of closely related variants have been found (with OXA numbers $64,65,66,67,68,69,70,71,75,76$, $77,83,84,86,87,88,89,91,92,94$, and 95) ${ }^{7}$, and they were referred collectively as "blaOXA-51-like" genes.

The resistance of $A$. baumannii to antimicrobial agents is mediated by all of the major resistance mechanisms that are known to occur in bacteria. $\beta$-lactamases are the most diverse group of enzymes that are associated with resistance, and more than 50 different enzymes, have been identified so far in $A$. baumannii. OXA-51-like carbapenemases are class $\mathrm{D} \beta$-lactamases which are intrinsic to $A$. baumannii and confer resistance to carbapenems ${ }^{5}$.

Nosocomial Acinetobacter baumannii is commonly acquired through cross-transmission because of its propensity to survive in the hospital environment and persistently contaminate fomites ${ }^{8}$.

This study aimed to isolation of different strains of Acinetobacter from Assiut University Hospital, detection of resistance pattern to different antibiotics, typing of different strains of Acinetobacter isolated, to determine the relatedness between strains isolated from environment and from patients by using different typing system as biotyping, antibiogram and genotyping, and finally phenotypic and genotypic detection of MetalloB-Lactamase enzyme (resistance enzyme blaOxa51-like gene).

\section{MATERIAL AND METHODS}

In this study, 440 clinical samples were obtained from 220 nosocomially infected patients and 672 environmental samples were collected from surfaces, walls, furniture, beds and trolleys of ICUs, different wards of Assiut University Hospital between the period of October 2009 to February 2011.

All samples were cultured on Nutrient agar, Nutrient broth, Blood agar base

MacConkey's agar, Herellea Agar, Muller Hinton agar, Eosin methylene blue, Triple sugar iron agar, Simmon's citrate medium, Semi-solid agar (3\%), Urea agar base and Peptone water (HiMedia). Further confirmation of isolates and biotyping of isolated strains had been performed by using API 20NE kit (BioMerieux, France).

Antimicrobial susceptibility pattern was done on isolated strains by using disc diffusion method (Kirby Baur method). The following Antimicrobial agents were used: Ampicillin (10 g), Amoxacillin-Clavulanic acid (20-10 g), (Piperacillin (30 g), cefaclor $(30 \mathrm{~g})$, cefuroxime $\left(\begin{array}{ll}30 \mathrm{~g}\end{array}\right)$, cefotaxime $\left(\begin{array}{ll}30 \mathrm{~g}\end{array}\right)$, ceftazidime $(30 \mathrm{~g})$, ceftriaxone $\left(\begin{array}{ll}30 \mathrm{~g}\end{array}\right)$, Amikacin (30 g), gentamicine (10 g), Tobramycin $(10 \mathrm{~g})$, Tetracycline $\left(\begin{array}{ll}30 & \mathrm{~g}\end{array}\right)$, ciprofloxacin $(10 \mathrm{~g})$, Imipenem $\left(\begin{array}{ll}10 & \mathrm{~g}\end{array}\right)$. (Oxoid). Results of these antimicrobial susceptibility pattern were interrupted according to CLSI guidelines".

Phenotypic detection of Metallo- $\beta$ Lactamase in Acinetobater isolates was done by using combined-disk test, two IPM disks (10 g), one containing $10 \quad 1$ of $0.1 \mathrm{M}(292 \mathrm{mg})$ anhydrous EDTA (Sigma Chemicals, St. Louis, MO), were placed $25 \mathrm{~mm}$ apart (center to center). An increase in zone diameter of $>4 \mathrm{~mm}$ around the IPM-EDTA disk compared to that of the IPM disk alone was considered positive for an $\mathrm{MBL}^{10}$.

Genotypic analysis of isolated Acinetobacter strains was done by using primers for detection 16S rRNA-23S rRNA gene, as shown in table 1.

Genotypic detection of Metallo- $\beta$ Lactamase in Acinetobater isolates was done by Multiplex PCR for bla-OXA-51-like gene and class I integrase enzyme. As shown in table 2.

Table 1: Sequence of 16S rRNA-23S rRNA gene primer ${ }^{11}$.

\begin{tabular}{||l|l||}
\hline \multicolumn{1}{|c|}{ Primer } & \multicolumn{1}{|c|}{$\begin{array}{c}\text { Oligonucleotide } \\
\text { sequence (5-3) }\end{array}$} \\
\hline $\begin{array}{l}\text { 16S-23S rRNA Gene } \\
\text { Spacer Region(1512)- F }\end{array}$ & $\begin{array}{l}\text { GTCGTAACAAGGTAGCC } \\
\text { GTA }\end{array}$ \\
16S-23S rRNA Gene & $\begin{array}{l}\text { GGGTTYCCCCRTTCRGAA } \\
\text { AT } \\
\text { Whacer Region (1512)- R Y is C or T and R is A } \\
\text { or G) }\end{array}$ \\
\hline
\end{tabular}


Table 2: Oligonucleotides primers used for amplification of blaOXA-51-gene and class 1 integrase gene by Multiplex PCR ${ }^{12 \& 13}$.

\begin{tabular}{|l|l|l|l|}
\hline \multicolumn{1}{|c|}{ Primer } & \multicolumn{1}{|c|}{ Sequence } & Target gene & \multicolumn{1}{c|}{$\begin{array}{c}\text { Amplicon } \\
\text { size (bp) }\end{array}$} \\
\hline OXA-51-likeF & 5_-TAA TGC TTT GAT CGG CCT TG-3_- & blaOXA-51-like & 353 \\
OXA-51-likeR & 5_-TGG ATT GCA CTT CAT CTT GG-3_- & blaOXA-51-like & \\
Int1F & 5_-CAG TGG ACA TAA GCC TGT TC-3_ & Class 1 integrase & 160 \\
Int1R & 5_-CCC GAG GCA TAG ACT GTA-3 & Class 1 integrase & \\
\hline
\end{tabular}

\section{RESULTS AND DISCUSSION}

\section{Results}

\section{Clinical samples}

Nosocomial infection rate during the period of the study was $2.3 \%$, as it was detected in 276 patients from total 11975 patients admitted to different ICUs and hospital wards who developed nosocomial infections during their hospitalization
Table 3 shows that 24 strains of Acinetobacter $(5.45 \%)$ were isolated from 440 clinical sample, 87 urine culture $(1.136 \%), 66$ sputum (1.82\%), 63 Endotracheal tube $(1.36 \%), 169$ blood culture $(0.23 \%), 20$ Throat swab $(0.68 \%), 33$ wound swab $(0.23 \%), 2$ nasal swab $(0 \%)$.

The high percentage of Acinetobacter strains isolate from sputum samples $(1.82 \%)$, Endotracheal tube $(1.36 \%)$. No Acinetobacter strains were detected in nasal swab.

Table 3: Isolation of Acinetobacter Sp. from different clinical sample.

\begin{tabular}{|l|c|c|c|c|c|c|c|c|c|}
\hline & \multirow{2}{*}{$\begin{array}{c}\text { Nample } \\
\text { Collected }\end{array}$} & $\begin{array}{c}\text { No. of } \\
\text { samples } \\
\text { collected }\end{array}$ & \multicolumn{2}{|c|}{ Gm-ve bacilli } & \multicolumn{2}{c|}{$\begin{array}{c}\text { Lactose } \\
\text { fermenter }\end{array}$} & \multicolumn{2}{|c|}{$\begin{array}{c}\text { Non Lactose } \\
\text { fermenter }\end{array}$} & \multicolumn{2}{|c|}{ Acinetobacter } \\
\cline { 5 - 12 } & No from & $\begin{array}{c}\text { total } \\
\text { sample }\end{array}$ & No & $\begin{array}{c}\% \text { from } \\
\text { total } \\
\text { sample }\end{array}$ & No & $\begin{array}{c}\% \text { from } \\
\text { total } \\
\text { sample }\end{array}$ & No & $\begin{array}{c}\% \text { from } \\
\text { total } \\
\text { sample }\end{array}$ \\
\hline Urine & 87 & 34 & $7.73 \%$ & 17 & $3.86 \%$ & 17 & $3.86 \%$ & 5 & $1.136 \%$ \\
\hline Sputum & 66 & 68 & $15.45 \%$ & 47 & $10.68 \%$ & 21 & $4.77 \%$ & 8 & $1.82 \%$ \\
\hline $\begin{array}{l}\text { Endotracheal } \\
\text { tube }\end{array}$ & 63 & 83 & $18.86 \%$ & 58 & $13.18 \%$ & 25 & $5.68 \%$ & 6 & $1.36 \%$ \\
\hline Blood culture & 169 & 33 & $7.5 \%$ & 31 & $7.045 \%$ & 2 & $0.45 \%$ & 1 & $0.23 \%$ \\
\hline Throat swab & 20 & 24 & $5.45 \%$ & 15 & $3.4 \%$ & 9 & $2.045 \%$ & 3 & $0.68 \%$ \\
\hline Wound swab & 33 & 36 & $8.18 \%$ & 26 & $5.9 \%$ & 10 & $2.27 \%$ & 1 & $0.23 \%$ \\
\hline Nasal swab & 2 & 0 & $0 \%$ & 0 & $0 \%$ & 0 & $0 \%$ & 0 & $0 \%$ \\
\hline Total & 440 & 278 & $63.18 \%$ & 194 & $44.09 \%$ & 84 & $19.09 \%$ & 24 & $5.45 \%$ \\
\hline
\end{tabular}

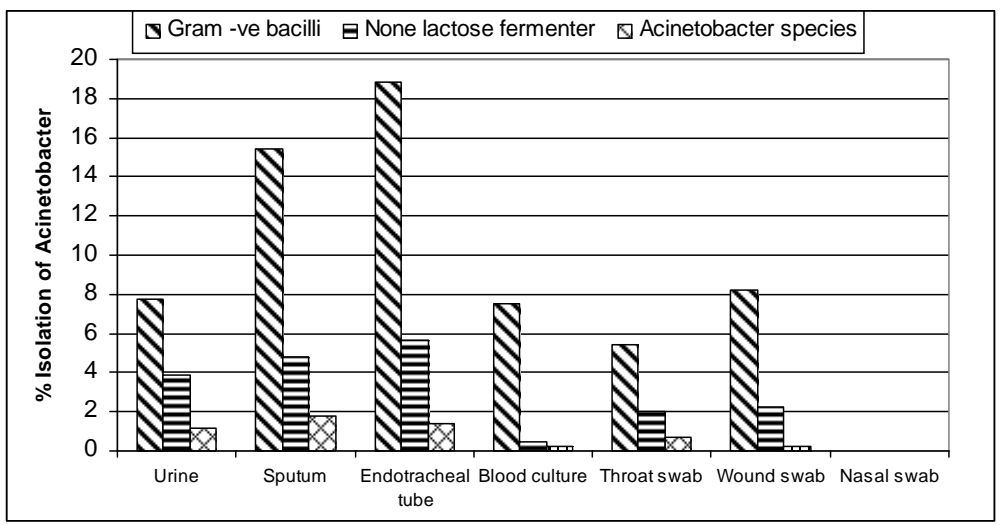

Fig. 1: Percentage of isolation of Acinetobacter from different clinical sample. 
Analysis of Environmental samples

Twenty-seven (27) strains of Acinetobacter were isolated from 672 environmental samples from different ICUs \& wards at Assiut university Hospital (4.017\%).

\section{Identification of Acinetobacter species}

All Acinetobacter strains were described as Gram negative cocco-bacilli, non motile, non spore forming, capsulated, oxidase negative, not reduce nitrate to nitrite, not ferment sugar and citrate positive.

Acinetobacter spp grew on blood agar showing mucoid colonies, grew on MacConkey agar showing non-lactose fermenter colonies, also grew on Herellea agar showing purple colonies.

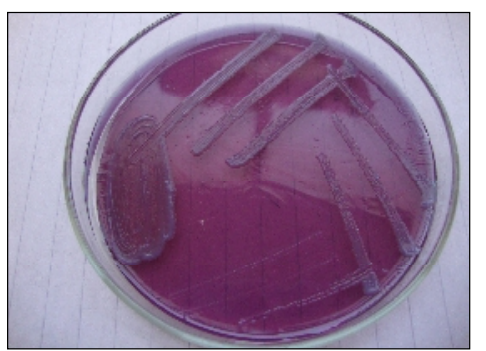

Fig. 2: Isolation of Acinetobacter on Herellea agar showing purple colonies.

\section{API 20 NE}

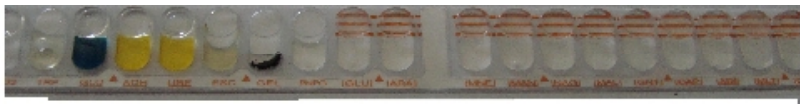

Fig. 3: API 20NE (Pattern no. 0040053: Acinetobacter baumannii/ colaecaticus).

\section{Antibiotic susceptibility pattern for isolated} Acinetobacter species

Table 4 shows that the resistance of Acinetobacter strains to Pencillin derivatives (Ampicillin, Amoxacillin-Clavulinic acid, Piperacillin) was $61.82 \%$, resistance of
Acinetobacter strains to Cephalosporines (Cefaclor, Cefataxime, Cefotrioxone, Cefatazidime) was $61.8 \%$, resistance of Acinetobacter strains to Monobactam (Aztronam) was $60.6 \%$, resistance of Acinetobacter strains to carbapenam (Imipenam) was $31.24 \%$, resistance of Acinetobacter strains to Quinolones (Ciprofloxacin) was $64.18 \%$, resistance of Acinetobacter strains to Tetracycline was 25.2\%, resistance of Acinetobacter strains to Aminoglycosides (Netlimicin, Tobramycin, Gentamicin and Amikacin) was 56.48\% and resistance of Acinetobacter strains to Chloramphenicol was $53.01 \%$

\section{Phenotypic detection of Metallo-B-lactamase by Combined Disc test}

(48/51 or $94.1 \%)$ of Acinetobacter isolates during this study showed increase zone of inhibition of about $4 \mathrm{~mm}$ or more around EDTA (0.1 M)-IPM disc compared to IPM disc alone

\section{Detection of 16s rRNA-23sr RNA gene} (intergenic spacer (ITS) region)

(49/51 or $96 \%$ ) of Acinetobacter $s p$ have ITS of 607-622. This means that strains may be A.baumanii or genomic species 3 and 13TU. (Fig. 4).

\section{Result of Multiplex PCR: Detection of bla} oxa- 51 like gene \& class I intgrase gene

(23/24 or $96 \%)$ of Acinetobacter isolate from clinical sample, (28/29 or $96.5 \%)$ of isolates from environmental result showed positive result for bla oxa-51-like gene (intrinsic carbapenamase gene) \& 18 Acinetobacter isolates from clinical sample, 21 isolates from environmental samples showed positive result for class I intgrase gene (Fig. 5).

Table 4: Resistance pattern of Acinetobacter isolates.

\begin{tabular}{|c|c|c|c|c|c|c|c|c|}
\hline \multirow{3}{*}{ Sample } & \multicolumn{8}{|c|}{ Resistance Pattern } \\
\hline & \multicolumn{4}{|c|}{$\beta$-lactam } & \multirow{2}{*}{ Quinolone } & \multirow{2}{*}{$\begin{array}{l}\text { Tetra- } \\
\text { cyclines }\end{array}$} & \multirow{2}{*}{$\begin{array}{l}\text { Amino- } \\
\text { glycosides }\end{array}$} & \multirow{2}{*}{$\begin{array}{l}\text { Chloram- } \\
\text { phenicol }\end{array}$} \\
\hline & $\begin{array}{l}\text { Penicillin } \\
\text { derivative }\end{array}$ & $\begin{array}{l}\text { Cephalo- } \\
\text { sporines }\end{array}$ & $\begin{array}{c}\text { Monobactam } \\
\text { Aztronam }\end{array}$ & $\begin{array}{c}\text { Carbapenam } \\
\text { Imipenam }\end{array}$ & & & & \\
\hline $\begin{array}{l}\text { Clinical } \\
\text { Sample }\end{array}$ & $66.67 \%$ & $62.5 \%$ & $58.33 \%$ & $29.16 \%$ & $66.67 \%$ & $20.83 \%$ & 58.33 & $54.17 \%$ \\
\hline $\begin{array}{c}\text { Environmnetal } \\
\text { sample }\end{array}$ & $56.97 \%$ & $61,11 \%$ & $62.96 \%$ & $33.33 \%$ & $62.96 \%$ & $29.6 \%$ & $54.63 \%$ & $51.85 \%$ \\
\hline $\begin{array}{l}\text { Main total } \\
\text { resistance }\end{array}$ & $61.82 \%$ & $61.8 \%$ & $60.6 \%$ & $31.24 \%$ & $64.18 \%$ & $25.2 \%$ & $56.48 \%$ & $53.01 \%$ \\
\hline
\end{tabular}




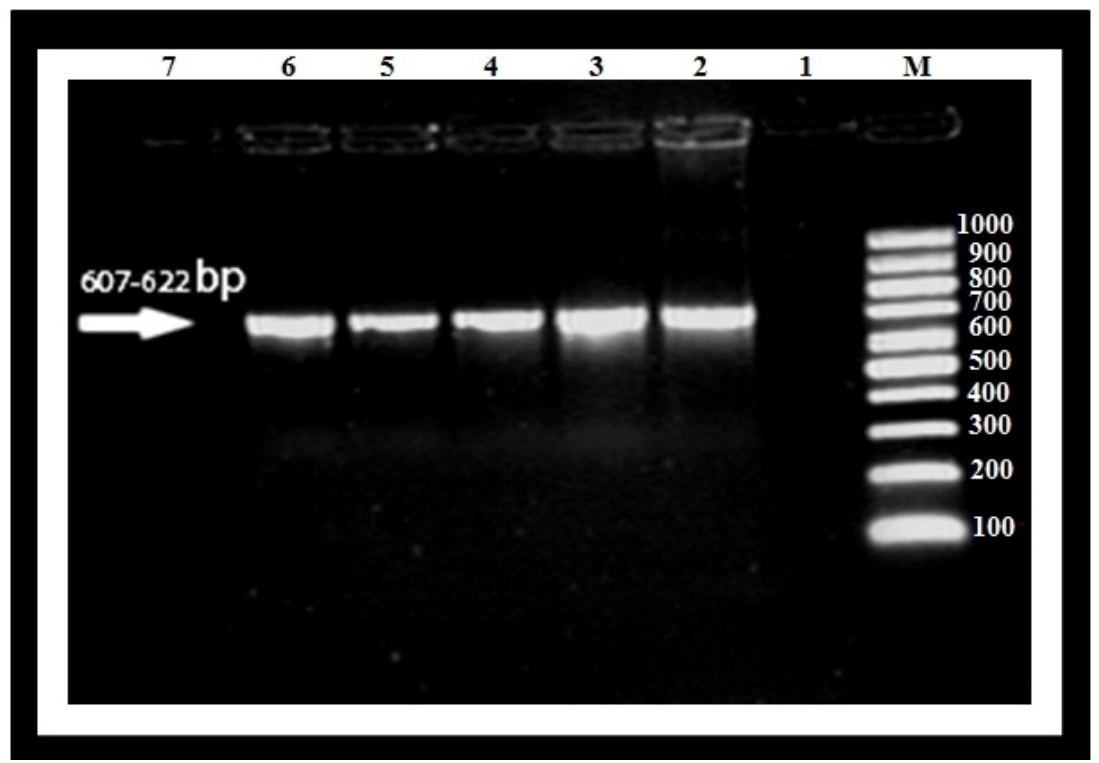

Fig. 4: PCR for detection 16s rRNA-23sr RNA gene (intergenic spacer (ITS). M: DNA marker (100 bp) Lane 1: Negative control Lane 2 : Positive control Lane 3 to Lane 6 : show positive result for the gene Lane 7: show negative result

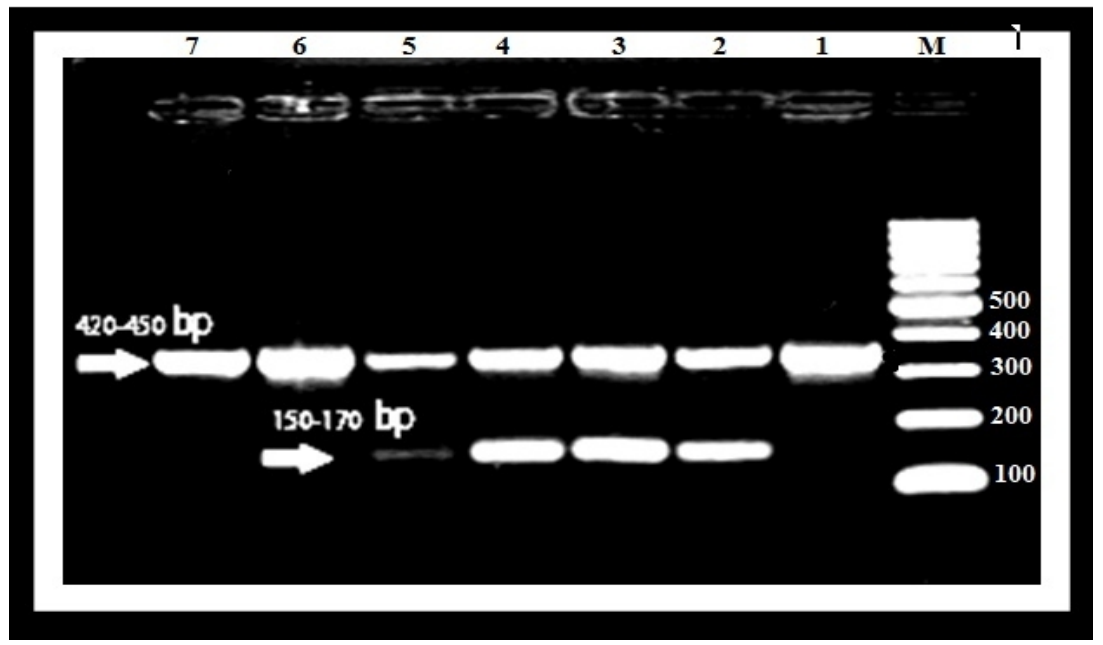

Fig. 5: Multiplex PCR for detection of bla-OXA 51 gene and class I integrase gene.

\section{Discussion}

In this study, out of 440 different specimens, 24 Acinetobacter isolates (5.45\%) were identified and Acinetobacter baumannii was the predominant among Acinetobacter isolates $(100 \%)$.

Out of 672 different environmental samples collected from beds, floors, walls, 27 Acinetobacter isolates $(4.017 \%)$ were identified.

Acinetobacter were isolated from respiratory specimens $(3.86 \%)$, urine $(1.136 \%)$, wound swab $(0.23 \%)$ and blood culture
$(0.23 \%)$. This agreed with results of ${ }^{14}$ that found that Acinetobacter spp were isolated from respiratory specimens $(51.7 \%)$, urine (24\%), swab from pus (13.7\%) and blood $(6.8 \%)$.

In this study, most Acinetobacter isolate were obtained from environmental and clinical sample from ICUs (82\%), this results is higher than that reported by Lone et al. ${ }^{15}$ who reported that Acinetobacter were the most prevalent in the intensive care unit $(29.84 \%)$.

Identification of Acinetobacter occured by API20NE. Also typing of Acinetobacter 
isolated from clinical sample and environmental samples occurs by using API 20NE. This agrees with Loubinoux et al. (2003) who reported that the identification of non fermenetative gram negative rods is usually carried out by using identification system such as the API 20 NE (bioMerieux).

The results of antimicrobial susceptibility test for isolated Acinetobacter species had shown resistance to penicillin derivatives (61.82\%), Cephalosporine derivatives (61.82\%), Quinolones (64.18\%), Monobactam (60.6\%), Aminoglycosides (56.48\%) and Chloarmphenicol (53.01\%). The lowest rate of resistance was detected to Imipenem (31.24\%) and tetracyclines $(25.2 \%)$. This agrees with Hashem et al. ${ }^{14}$ who showed that Tetracycline was the most effective antimicrobial agent against $A$. baumannii.

MBL-carrying organisms can appear susceptible to carbapenems using current Clinical and Laboratory Standards Institute or British Society for Antimicrobial Chemotherapy breakpoints ${ }^{7 \& 9}$. MBL producing organisms pose significant risks, particularly due to their role in unnoticed spread within institutions and their ability to participate in horizontal MBL gene transfer with other pathogenic hospital-related organisms ${ }^{16}$.

Carbapenem treatment for infections caused by carbapenem-susceptible MBLcarrying organisms (hidden MBLs) is currently unknown, but the ability of these isolates to participate in horizontal MBL gene transfer with other gram-negative pathogens and contribute significantly to MBL-related outbreaks has been described ${ }^{16}$. As a consequence, more sensitive means of laboratory detection of MBL-producing isolates are urgently required if we are to prevent the ongoing spread of these problematic organisms.

In Combined disc test (48/51 or $94.1 \%)$ of Acinetobacter isolates showed increase in zone of inhibition around IPM/EDTA disc compared with IPM disc alone. This agree with Baron $e t$ $a l .{ }^{17}$, who showed that Combined disc test is most specific, easiest, cheapest and sensitive laboratory method for detection of metallo- $\beta$ lactamse enzymes is $\mathrm{Gm}$-ve bacilli isolates

In this study, 49 Acinetobacter isolates (96\%) were detected by presence of 16srRNA 23srRNA gene (universal gene present in all
Acinetobacter species), Acinetobacter isolates show ITS (607-622 bp). (49/51 or 96\%) of isolated Acinetobacter showed band with blaOXA-51-like" genes., this agrees with Turton et al. ${ }^{5}, 141$ isolates of A. baumannii found, representing 23 genotypes, gave a band in the blaOXA-51-like PCR, clearly suggesting that this PCR does detect these genes in all the isolates of $A$. baumannii we currently encounter, but we remain alert to the possibility of non detection of some variants. A further potential problem is that these genes are sometimes associated with ISAbal ${ }^{5}$ which may render them mobile

In this study, (37/51 or $72.5 \%)$ of Acinetobacter isolates showed positive bands for class I integrase gene (gene responsible for multi drug resistance and outbreaks in hospitals). The analysis of A. baumannii strains with known epidemic behavior demonstrates that early identification of epidemic strains may be possible by detection of integrons or multiple antibiotic resistance. The integrase gene PCR identified almost $75 \%$ of the epidemic A. baumannii strains. Multiple antibiotic resistance, defined as resistance to five or more antibiotics, showed good correlation with the presence of integrons and epidemic behavior of the strains.

\section{Conclusion}

1- Acinetobacter baumannii is an important nosocomial pathogens in Assiut University hospital.

2- Sputum, urine and endotracheal tubes were the commonest source of Acinetobacter infection followed by throat swab, blood culture and wound swab.

3- The most important antibiotics that are effective in treatment of multi-drug resistant Acinetobacter baumannii are tetracycline followed by imipenem

4- Presence of imipenem susceptible Acinetobacter baumannii that harbor resistance gene (hidden gene) represent major problem in transmission of resistance gene among members of $\mathrm{Gm}$-ve bacilli.

5- Result of Multiplex PCR shows that outbreak from Acinetobater baumannii is present in Assiut university hospital, as presence of integrase gene in isolated Acinetobacter strains means that these strains have potential epidemic prosperities, 
so infection control measures must be applied to reduce these infections

6- The most important risk factors for nosocomial infection are patients in intensive care units, patients under mechanical ventilation, urinary catheterized patients and immunocompromised patients

7- Role of detection of 16rrRNA gene by convential PCR is detection of presence of Acinetobacter as it is a universal gene (607$622 \mathrm{bp}$ is indication of Acinetobacter baumannii-Colecaeticus complex).

\section{REFERENCES}

1- V. A. Gant, M. W. Wren, M. S. Rollin, A. Jeanes, S. S. Hickok and T. J. Hall, "Three noval highly effective charged copperbased biocides; safety and efficacy against health care-associated organisms", J. Antimicrob. Chemother., 60, 294-299 (2007).

2- B. Pedro, L. Teles, L. Cabral and C. Cruzeiro, "Multiresistant Acinetobacter infection in a burns unit", Annals of Burns and Fire Disasters, XIV (4), 354-358 (2001).

3- H. Po-Ren, T. Lee-Jene, C. Cheng-Yi, C.Wen-Hwei, Y. Chong-Jen, H. Shen-Wu and L. Kwen-Tay, "Pandrug-Resistant Acinetobacter baumannii causing nosocomial infections in a University Hospital, Taiwan", Emerging Infectious Diseases, 8 (8), 466-472, August (2002).

4- C. Zeana, E. Larson, J. Sahni, S. J. Bayuga, F. Wu and P. Della-Latta, "The epidemiology of multidrug-resistant Acinetobacter baumannii: does the community represent a reservoir?", Infect. Control. Hosp. Epidemiol., 24, 275-9 (2003).

5- J. F. Turton, M. E. Ward, N. Woodford, M. E. Kaufmann, R. Pike, D. M. Livermore and T. L. Pitt, "The role of ISAbal in expression of OXA carbapenemase genes in Acinetobacter baumannii", FEMS Microbiol. Lett., 258, 72-77 (2006).

6- S. Brown, H. K. Young and S. G. B. Amyes, "Characterisation of OXA-51, a novel class $\mathrm{D}$ carbapenemase found in genetically unrelated clinical strains of Acinetobacter baumannii from
Argentina", Clin. Microbiol. Infect., 11, 15-23 (2005).

7- J. M. Andrews, "BSAC standardized disc susceptibility testing method (version 4)", J. Antimicrob. Chemother., 56, 60-76 (2005).

8- A. Borer., J. Gilad, R. Smolyakov, S. Eskira, N. Peled, N. Porat, E. Hyam, R. Trefler, K. Riesenberg and F. Schlaeffer, "Cell Phones and Acinetobacter Transmission", Emerging Infectious Diseases, 11 (7), (2005).

9- Clinical and Laboratory Standards Institute/NCCLS, "Performance Standards for Antimicrobial Susceptibility Testing" $15^{\text {th }} \quad$ Informational Supplement. CLSI/NCCLS M100-S15. Clinical and Laboratory Standards Institute, Wayne, Pa., (2005).

10- J. J. Yan, J. J. Wu, S. H. Tsai and C. L. Chuang, "Comparison of the double-disk, combined disk, and Etest methods for detecting metallo-betalactamases in gramnegative bacilli.", Diagn. Microbiol. Infect. Dis., 49, 5-11 (2004).

11- D. A. Relman, "Universal Bacterial 16S rDNA Amplification and Sequencing", In: D. H. Persing, T. F. Smith, F. C. Tenover, and T. J. White (ed.), "Diagnostic Molecular Microbiology", American Society for Microbiology, Washington, D.C., 1993, pp. 489-495.

12- J. G. M. Koeleman, J. Stoof, M. W. van der Bijl, C. M. J. E. VandenbrouckeGrauls and P. H. M. Savelkoul, "Identification of epidemic strains of Acinetobacter baumannii by integrase gene PCR.", J. Clin. Microbiol., 39, 8-13 (2001).

13- N. Woodford, M. J. Ellington, J. M. Coelho, J. F. Turton, M. E. Ward, S. Brown, S. G. B. Amyes and D. M. Livermore,. "Multiplex PCR for genes encoding prevalent OXA carbapenemases in Acinetobacter spp.", Int. J. Antimicrob. Agents, 27, 351-353 (2006).

14- S. Hashem, S. Fekry, A. Mohammed and S. Doaa, "Multidrug resistant Egyptian isolates of Acinetobacter baumannii.", J. Americ. Science, 7 (1), (2011).

15- R. Lone, A. Shah, SM. Kadri, S. Lone and S. Faisal, "Nosocomial Multi-drug resistant acinetobacter infections clinical 
findings, risk factors and demographic characteristics, Bangladesh", J. Med. Microbiol., 3 (1), 34-38 (2009).

16- A. Y. Peleg, C. Franklin, J. M. Bell and D. W. Spelman, "Dissemination of the metallo-beta-lactamase gene blaIMP-4 among gram-negative pathogens in a clinical setting in Australia", Clin. Infect. Dis., 41, 1549-1556 (2005).
17- E. J. Baron., L. R. Peterson and S. M. Fingold, (eds.), "Conventional and Rapid Microbiological Methods for Identification of Bacteria and Fungi", In: Baily and Scott's Diagnostic Microbiology, $9^{\text {th }}$ Ed. Chap. 10, St. louis, C.V. Mosby Co., saint Louis, USA, 1994, pp. 97-123. 


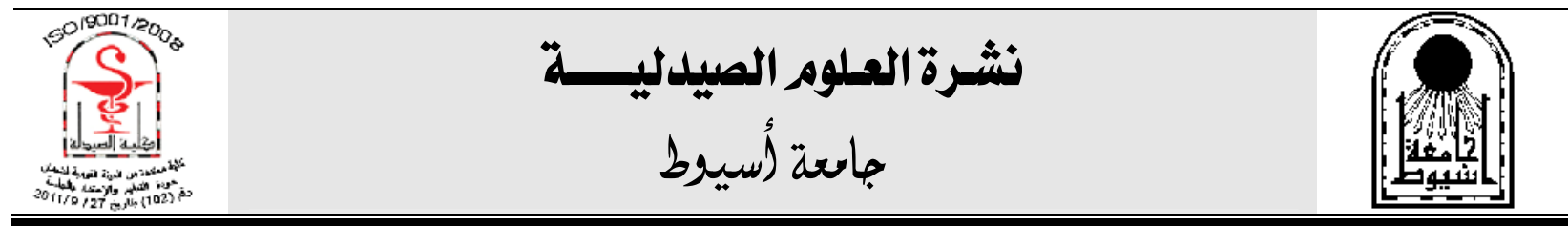

\section{عدوى المستشفيات المكتسبة من ميكروب الاسينيتوباكتر

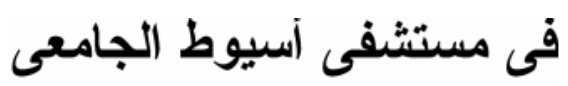
اسماعيل صادق سليمان - احمد صادق احمد - ايناس عبد المجيا - ابراهيم محمد سيا قسم الميكروبيولوجيا والمناعة ، كلية الطب ، جامعة أسيوط ، مصر

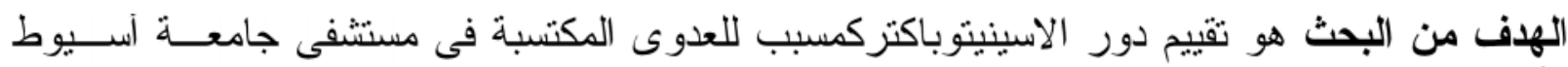

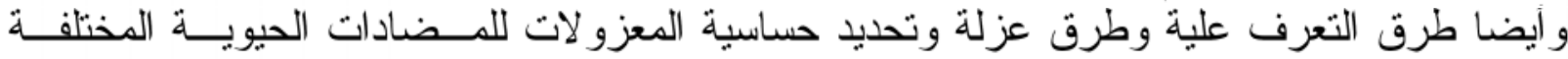

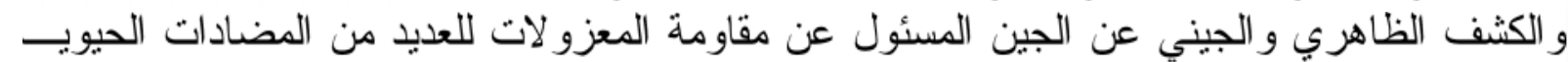

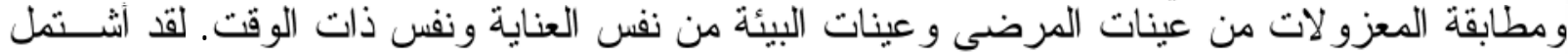

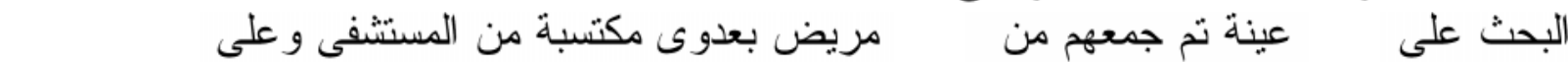

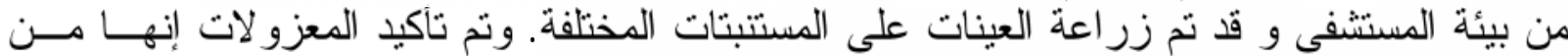

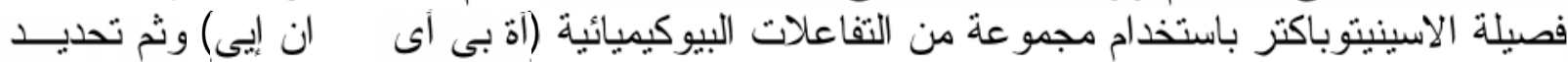

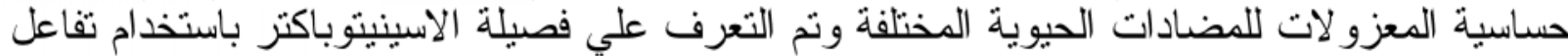

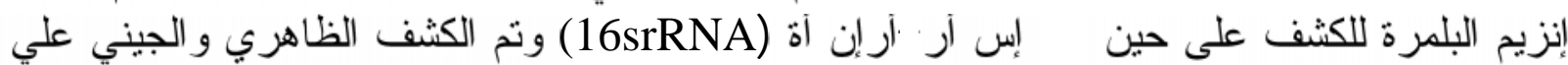
(bla-OXA-51)

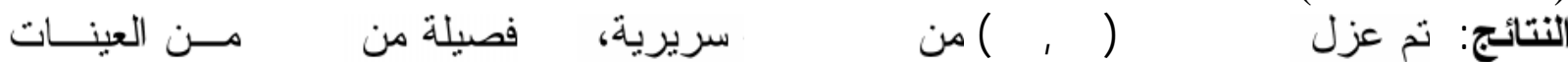

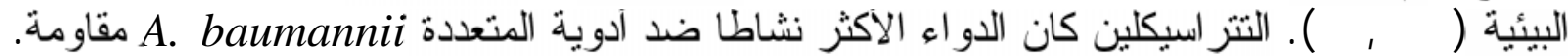

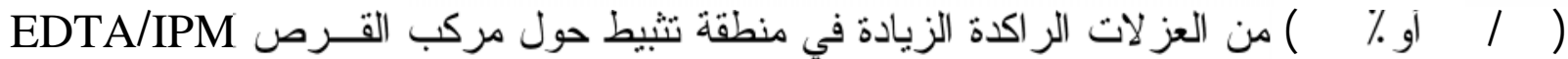

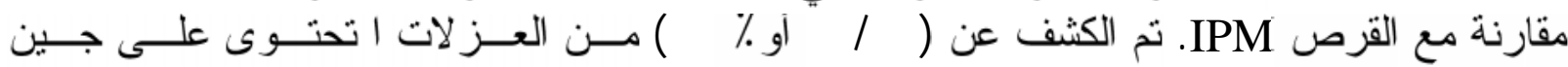
23srRNA 16srRNA

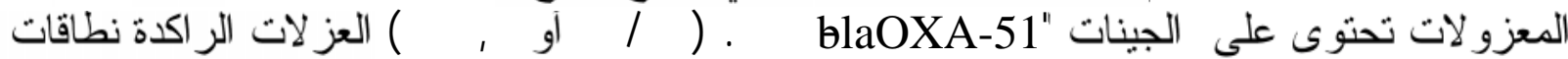

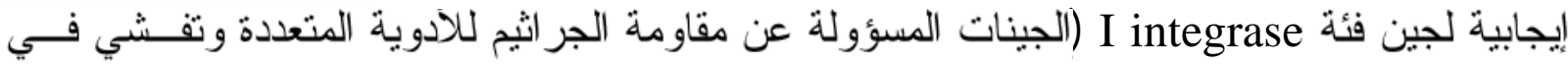

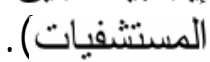

